\title{
Win - and stay, but not too long: cavity selection by Boreal Owls to minimize nest predation by Pine Marten
}

\author{
Geir A. Sonerud ${ }^{1}$ (i) \\ Received: 13 October 2020 / Revised: 12 February 2021 / Accepted: 26 February 2021 / Published online: 13 March 2021 \\ (c) The Author(s) 2021
}

\begin{abstract}
Site fidelity after successful nesting and site shift after nest predation (win-stay, lose-shift) is a well-documented adaptation to spatially heterogeneous and temporally auto-correlated predation risk. However, site shift even after a successful nesting (win-shift) may become a better tactic than site fidelity (win-stay), if a successful nest site becomes more risky until the next nesting opportunity, and if new low-risk nest sites regularly appear. Correspondingly, selecting a new non-used nest site may become a better tactic than selecting one previously used successfully by a conspecific. I studied this dynamic by focusing on nest cavities that may be available for many years, and using nest boxes to allow an experimental design. At localities where Boreal Owls (Aegolius funereus) had nested successfully, a dyad of nest boxes was made available each year, one box in the original nest tree and one in a new tree for the season, each containing either old nest material from the successful nesting or new wood shavings. Boreal owls were more likely to select the box in the new tree when more years had elapsed since the successful nesting and since a box was installed in the original nest tree, independent of box content. The pattern of selection differed between young and old individuals for males, but not females. Young males based their selection of nest tree mainly on box content, while old males based it on time elapsed since the successful nesting in the original nest tree and how long a box had been present there. The probability of depredation of Boreal Owl nests by Pine Marten (Martes martes) has previously been found to increase with cavity age and number of nesting seasons elapsed since the previous successful nesting. This pattern of nest predation thus predicted the pattern of nest site selection found.
\end{abstract}

Keywords Aegolius funereus $\cdot$ Antipredator defense $\cdot$ Breeding dispersal $\cdot$ Cavity nesting $\cdot$ Martes martes $\cdot$ Nest-site selection

\section{Zusammenfassung}

Gewinne - und bleibe, aber nicht zu lange: Höhlenwahl von Raufußkäuzen zur Minimierung der Nesträuberei durch Baummarder.

Standorttreue nach erfolgreichem Brutgeschäft und Standortwechsel nach Nesträuberei (win-stay, loose-shift) ist eine gut dokumentierte Anpassung an das räumlich heterogene und zeitlich autokorrelierte Risiko, erbeutet zu werden. Aber ein Standortwechsel selbst nach einem erfolgreichen Brutgeschäft (win-shift) kann eine noch bessere Taktik sein als Standorttreue (win-stay), wenn ein erfolgreicher Nistplatz bis zur nächsten Nistgelegenheit riskanter wird und wenn neue, risikoarme Nistplätze regelmäßig zur Verfügung stehen. Dementsprechend kann die Auswahl eines neuen, bisher nicht genutzten Nistplatzes zu einer besseren Taktik werden als die Auswahl eines zuvor erfolgreich von einem Artgenossen genutzten. Ich untersuchte diese Dynamik, indem ich mich auf Nisthöhlen konzentrierte, die über viele Jahre hinweg verfügbar sein konnten und indem ich Nistkästen verwendete, an denen ich experimentieren konnte. An Standorten, an

Communicated by O. Krüger.

Geir A. Sonerud

geir.sonerud@nmbu.no

1 Faculty of Environmental Sciences and Natural Resource Management, Norwegian University of Life Sciences, P. O. Box 5003, NO-1432 Ås, Norway 
denen der Raufußkauz (Aegolius funereus) erfolgreich genistet hatte, wurde jedes Jahr ein Paar Nistkästen angeboten: ein Kasten im ursprünglichen Nistbaum und einer in einem für diese Saison neuen Baum; beide Kästen enthielten entweder altes Nestmaterial aus dem Nest mit der erfolgreichen Brut oder neue Hobelspäne. Unabhängig vom Kasteninhalt wählten die Eulen mit höherer Wahrscheinlichkeit den Kasten im neuen Baum, wenn mehr Jahre seit dem erfolgreichen Brutgeschäft und seit der Anbringung eines Kastens im ursprünglichen Nestbaum vergangen waren. Das Muster, nach dem sie ihre Wahl trafen, unterschied sich zwischen jungen und alten Männchen, aber nicht bei den Weibchen. Bei der Auswahl des Nistbaums richteten sich junge Männchen hauptsächlich nach dem Inhalt des Kastens, während alte Männchen eher danach gingen, wie viel Zeit seit dem erfolgreichen Brutgeschäft im ursprünglichen Nistbaum vergangen und wie lange ein Nistkasten dort schon vorhanden war. Es wurde schon früher festgestellt, dass die Wahrscheinlichkeit einer Plünderung von Eulennestern durch Baummarder (Martes martes) mit dem Alter der Nisthöhle und der Anzahl der seit der letzten erfolgreichen Brut verstrichenen Nestsaisons zunimmt. Dieses Muster des Nestausraubens war somit ein Prädiktor für das beobachtete Muster der Wahl eines Nests.

\section{Introduction}

Selection of oviposition sites by animals in general, and selection of nest sites by birds in particular, is assumed to have fitness consequences. However, clear demonstrations of adaptive nest-site preferences would need to reveal the ongoing natural selection processes, e.g., how successful sites differ from unsuccessful sites, which are subtler than the patterns emerging over evolutionary time, e.g., how used sites differ from unused sites (Martin 1998; Clark and Shutler 1999; Latif et al. 2012). A major factor lowering reproductive success in birds is nest predation, which is an important factor in the evolution of avian behavior and life histories (e.g., Martin 1988, 1995; Martin and Clobert 1996; Pöysä 1999; Martin et al. 2000; Caro 2005; Fontaine and Martin 2006; Lima 2009; Chalfoun and Schmidt 2012; IbanezAlamo et al. 2015). Therefore, birds would be expected to select nest sites so as to minimize the risk of nest predation, resulting in a pattern of preferred nest sites exposing birds to lower predation risk than non-preferred nest sites (e.g., Sonerud 1985a,b; Martin 1998; Pöysä 1999; Schmidt and Whelan 1999; Rolstad et al. 2000; Latif et al. 2012). Few birds are able to defend their eggs or nestlings against all predators, and many, therefore, rely on selecting nest sites that minimize the probability of initial detection by nest predators (e.g., Caro 2005; Schmidt et al. 2006; Chalfoun and Martin 2010). How birds assess risk of nest predation, however, is still unclear (Lima 2009). The cost of acquiring the information needed for this assessment should not exceed the benefit of lowered risk of nest predation (Dall et al. 2005).

Among birds building their own nests, some make durable constructions that may be reused several times. Such birds, e.g., woodpeckers making cavities, have the option of reusing the original nest or constructing a new one (e.g., Nilsson et al. 1991; Rolstad et al. 2000; Aitken et al. 2002; Wiebe et al. 2007; Wesolowski 2011; Edworthy et al. 2018; Otterbeck et al. 2019). Correspondingly, birds depending on others for nest site construction, e.g., non-excavating cavity nesters, have the option of reusing the previous nest site or occupying another one (e.g., Aitken et al. 2002; Edworthy et al. 2018). Risk of nest predation, which is higher for nonexcavating cavity nesters than for excavators ( $\mathrm{Li}$ and Martin 1991; Martin and Li 1992), may play an important part in a bird's decision among these options. Estimating this risk may be based on private information as well as public information (Chalfoun and Schmidt 2012), both when the options to select between are the bird's own successful nest site and a new one, and when they are a conspecific's successful nest site and a new one.

Site fidelity after successful nesting and site shift after nest predation [win-stay, lose-shift (WSLS)] is a well-documented adaptation to spatially heterogeneous and temporally auto-correlated predation risk in birds (e.g., Dow and Fredga 1983, 1985; Haas 1998; Hoover 2003; Schmidt et al. 2006; Chalfoun and Martin 2010; Chalfoun and Schmidt 2012). Based on its own reproductive success (private information), or the reproductive success of conspecifics (public information), a bird apparently assesses the potential future predation risk at the site and responds by staying in (or returning to) low-risk sites and abandoning high-risk sites (Pöysä 1999; Hoover 2003; Schmidt et al. 2006; Chalfoun and Martin 2010; Karell et al. 2020). However, if originally low-risk sites predictably become more risky until the next nesting opportunity, and if new low-risk sites regularly appear, site fidelity would not necessarily be the best tactic after a successful nesting. This hypothesis predicts that nest site fidelity should be highest when risk of nest predation at sites where the previous nesting was successful increases slowly until the next nesting attempt there, and risk of nest predation at alternative new sites is high. Correspondingly, the hypothesis predicts that the nest fidelity should be lowest when risk of nest predation at sites where the previous nesting was successful increases rapidly until the next nesting attempt there, and risk of nest predation at alternative new nest sites is low. In the same way that this applies to assessment by private information, it applies to assessment by public information, i.e., selecting between new nest sites and 
nest sites used successfully by conspecifics. Such assessment would follow a Bayesian rule (cf. Luttbeg 1996), which will outperform the simple WSLS rule (Chalfoun and Schmidt 2012). This temporally and spatially dynamic aspect of nest predation risk has hitherto been little explored. I studied this dynamic by focusing on long-lasting nesting cavities that may be used by non-excavators for many years (Wesolowski 2011), and using nest boxes as cavity surrogates to allow an experimental study.

The Black Woodpecker (Dryocopus martius) excavates cavities that later serve as nest sites for the Boreal Owl (Aegolius funereus). Both are exposed to a significant nest predation by the Pine Marten (Martes martes) in the western Palearctic (Sonerud 1985a, b; Nilsson et al. 1991; Johnsson 1993; Rolstad et al. 2000; Zarybnicka et al. 2015). Pine Martens are medium-sized (c. $1 \mathrm{~kg}$ ) tree-climbing mustelids with relatively large home ranges (on average $7 \mathrm{~km}^{2}$ at $60^{\circ} \mathrm{N}$ in Sweden and Norway) and a generalist diet (Brainerd 1997; Helldin 1999). Although Pine Martens spend most time on the ground and prey mainly on small mammals (Pulliainen and Ollimäki 1996; Helldin 2000), they visit cavities year round and use them for roosting, denning and food storing (Sonerud 1985b; Brainerd et al. 1995), and would take any prey that may happen to be there, including eggs and nestlings. Most incubating or brooding Boreal Owl females survive nest predation, by rapidly jumping up in the cavity entrance, and if needed flying away, when a potential nest predator approaches or enters the trunk of the nest tree (Sonerud 1985b; Sonerud et al. 1988).

My study differs in several aspects from most other studies on avian nest predation. First, the majority of other such studies have dealt with passerines, and most with open-cup nesters (e.g., Martin 1988, 1998; Martin et al. 2000; Fontaine and Martin 2006; Schmidt et al. 2006; Latif et al. 2012; Ibanez-Alamo et al. 2015; Bellamy et al. 2018; Shitikov et al. 2018), nesting at a much higher density than cavity-nesting owls. Second, open-cup nesting passerines are exposed to a range of mostly quite small predators, such as corvids, rodents and snakes (e.g., Martin 1998; Fontaine and Martin 2006; Benson et al. 2010; Chalfoun and Martin 2010; DeGregorio et al. 2014; Bellamy et al. 2018; Shitikov et al. 2018), with smaller home ranges than Pine Martens. Therefore, the spatial scale of my study is of a magnitude larger than most other studies on avian nest predation, with nearest neighbor distance of the prey and home range of the predator on the scale of kilometers rather than meters. Studies of nest predation made on the same scale as mine are other on cavity nesters with the Pine Marten as the main predator, namely studies of the Black Woodpecker (e.g., Nilsson et al. 1991; Rolstad et al. 2000), the Boreal Owl (e.g., Zarybnicka et al. 2015), the Tawny Owl (Strix aluco) (Karell et al. 2020) and the Goldeneye (Bucephala clangula) (e.g., Dow and
Fredga 1983), as well as a study on the ground-nesting Capercaillie (Tetrao urogallus) and Black Grouse (Lyrurus tetrix) with Pine Marten and Red Fox (Vulpes vulpes) as predators (Jahren et al. 2017).

The probability of depredation by Pine Martens on Boreal Owl nests in boxes has been found to increase with number of years the box had been present in the same tree (Sonerud 1985a, 1989, 1993). Similarly, predation on Black Woodpecker nests was higher in reused cavities than in cavities excavated for the season (Nilsson et al. 1991, but see Rolstad et al. 2000). Moreover, depredation on nests of Goldeneye and Boreal Owl was higher in boxes where the previous nest was depredated than in boxes where the previous nesting was successful (Dow and Fredga 1983; Sonerud 1985a). One explanation for these two patterns is that a Pine Marten remembers the location of cavities it has found, and revisits them each nesting season (Sonerud 1985a; Elmberg and Pöysä 2011). Another not mutually excluding explanation for the latter pattern is the site effect, i.e., that some nest sites are simply more exposed to predators than others (Martin et al. 2000). Enhanced risk of nest predation in older cavities and in cavities where the previous nest was taken, as a result of the predator's long-term spatial memory, would select for excavators that make a new nest cavity for each nesting attempt and for non-excavators that prefer to nest in 1-year-old cavities and shift nest site more often after nest predation than after a successful nesting (Sonerud 1985a; Elmberg and Pöysä 2011). Indeed, Black Woodpeckers made a new cavity in $70 \%$ of the nesting events (Nilsson et al. 1991; Rolstad et al. 2000), and Boreal Owls nested more frequently in new boxes than in older ones (Sonerud 1985a). Moreover, in the Boreal Owl, females dispersed longer after nest predation than after successful nesting (Sonerud et al. 1988), and males shifted nest site more often and dispersed longer after being experimentally exposed to a caged Mink (Mustela vison) at the nest (Hakkarainen et al. 2001). Thus, Boreal Owls are seemingly able to assess nest predation risk and select cavities accordingly (Sonerud 1985a). Which cues they use are poorly known, however.

A Boreal Owl clutch laid in a box where the previous nesting was successful was more likely to be depredated by Pine Marten if the box had been unused for at least one nesting season in between than if the previous nesting had taken place the previous year (Sonerud 1985a). This suggests that Pine Martens also revisited boxes that they initially found empty (Sonerud 1985a), probably because they used boxes for roosting, denning and food storing (see above). The probability of depredation was lowest for Boreal Owl clutches in boxes not previously used and for clutches in boxes where there was a successful nesting the preceding year (Sonerud 1985a). This predation pattern would select for Boreal Owls that reuse a box only the year after a nesting was successful there, whether this nesting was its own or one 
of a conspecific, and otherwise select a nest box not previously used (Sonerud 1985a, cf. Mitchell and Lima 2002).

To test whether the pattern of cavity selection in Boreal Owls minimizes probability of nest predation, and to reveal which cues these owls use in assessing predation risk, I carried out a long-term field experiment. At localities where the previous nesting was successful, Boreal Owls could each year select between two nest boxes; one box in the original nest tree and one box in a new tree for the season. The experiment consisted of three treatments manipulating the box content, designed to test whether Boreal Owls select a cavity based on its spatial position or on information conveyed by its current content. By presenting two alternatives at each nesting locality I was able to separate the selection of nest site from the selection of territory. I predicted that the owls would select between the two options so as to minimize the risk of nest predation, i.e., to be more inclined to choose the box in the new tree as more years had passed since the successful nesting in the original tree, and the longer a box had been present there, independent of box content.

\section{Methods}

\section{Study species}

In the western Palearctic, Boreal Owls nest mostly in cavities excavated by the Black Woodpecker (e.g., Cramp 1985). However, they readily accept nest boxes, which makes experimental studies feasible. Boreal owls are small (male body mass c. $100 \mathrm{~g}$ ) and nocturnal, and subsist mainly on small mammals (Cramp 1985). Due to the strong numerical response of Boreal Owls to microtine rodents at northern latitudes (Korpimäki and Hakkarainen 1991), very few territories in my study area support nesting each year, and most only 1-2 nestings per 3-4 year microtine population cycle (Sonerud 1985a). Adult males are usually locally resident, whereas adult females may disperse widely between successive nesting attempts in response to the regionally asynchronous 3-4 year population fluctuations of microtine rodents (e.g., Löfgren et al. 1986; Korpimäki et al. 1987; Sonerud et al. 1988; Korpimäki 1993; Hakkarainen et al. 2001). Since natal as well as female breeding dispersal is extensive (e.g., Löfgren et al. 1986; Korpimäki et al. 1987; Sonerud et al. 1988), causing genetic swamping over large areas (Mysterud 1970; Koopman et al. 2005), selection for local adaptations is probably weak. Nest-site selection depends mostly on the male (Hakkarainen and Korpimäki 1998; Hakkarainen et al. 2001), who provides all prey for the family as long as the nestlings are being brooded, and most or all prey thereafter until the young become independent (Eldegard and Sonerud 2009, 2010, 2012). The young fledge at an age of 4-5 weeks (Eldegard and Sonerud 2012). After having been successfully used for nesting, a nest cavity contains an accumulated layer of feces and compressed pellets of undigested prey remains from the nestlings (Cramp 1985), hereafter termed old nest material. Most nest predation occurs during the 4-6 weeks long period of egg laying and incubation (94\% (Sonerud 1985a); 77\% (Zarybnicka et al. 2015)), so that until the next nesting attempt the presence of old nest material in a box is a quite reliable cue that the previous nest escaped depredation. The pattern of depredation may partly be ascribed to the spatial memory of the individual predator, i.e., that the predator regularly revisits cavities it has previously found (Sonerud 1985a), and partly to the site effect, i.e., that some nest sites are simply more exposed to predators than others (Martin et al. 2000).

\section{Study area}

The study was conducted during 1985-2007 at altitudes ranging $160-580 \mathrm{~m}$ within $60^{\circ} 00^{\prime}-62^{\circ} 03^{\prime} \mathrm{N}$ and $11^{\circ} 03^{\prime}-12^{\circ} 23^{\prime} \mathrm{E}$ in Hedmark county in southeastern Norway. The study area is situated in the boreal zone and covered by coniferous forest managed through harvesting by unselective clear-cutting, regeneration by planting, and thinning by selective cutting. It includes area III in the study of Sonerud (1985b) and the study area of Steen et al. (1996), and areas in between. Thus, it spans much wider than the study area of Sonerud (1985a), which it partly circumscribes, but does not overlap.

\section{Nest boxes}

Boxes made of wooden board, lined with a 5-10 cm deep layer of fine wood shavings covering the bottom, were installed $5 \mathrm{~m}$ above ground. They were accessed using ladders, and inspected by removing the roof. The boxes were from two "cohorts". The first was used in 1985-1995 (15 cases in the analysis below), and had an inner bottom area of c. $19 \mathrm{~cm} \times 19 \mathrm{~cm}$, a depth (below the entrance hole) of c. $22 \mathrm{~cm}$, and a circular entrance hole with diameter c. $11 \mathrm{~cm}$, with some inter-box variation. The second was used in 1991-2007 (63 cases in the analysis below), and had an inner bottom area of c. $20 \mathrm{~cm} \times 20 \mathrm{~cm}$, a depth of c. $30 \mathrm{~cm}$, a circular entrance hole with diameter c. $10 \mathrm{~cm}$, with no inter-box variation. In comparison, cavities excavated by the Black Woodpecker in Sweden were on average $7 \mathrm{~m}$ above ground, and had a depth of $31 \mathrm{~cm}$ and an entrance $8 \mathrm{~cm}$ wide and $11 \mathrm{~cm}$ high (Johnsson et al. 1993). Black Woodpecker cavities in southeastern Norway had similar measures (Rolstad et al. 2000). The boxes were placed in habitats so as to maximize the probability of use by Boreal Owls, and hence installed in single trees in clear-cut areas if possible, or in trees in edges between clear-cuts and old forest (cf. Sonerud 1985b). This also reflected the habitat preferences of Black 
Woodpeckers selecting a tree in which to excavate a nesting cavity (see Rolstad et al. 2000).

Each box was visited several times between late March and early July each year to record the onset and outcome of nesting attempts by Boreal Owls (date of egg laying, clutch size, whether the nest was taken by a predator (see Sonerud $(1985 a, b)$ for methods), and number of young fledged), and to band adults and fledglings.

The term locality denotes one box until the first successful nesting there by Boreal Owl, and a dyad of boxes in the years thereafter (see below). The study was based on a total of 239 nesting attempts by Boreal Owls, recorded at 100 localities, with 1-7 attempts per locality.

\section{Experimental procedure}

I conducted three treatments at each locality if possible (Fig. 1). In treatment 1, the box in which Boreal Owls had nested successfully (in year $n$ ) was relocated with its content of old nest material, and a box lined with new wood shavings was installed in its place, between September (in year $n$ ) and April (in year $n+1$ ). If none of the two boxes was used for

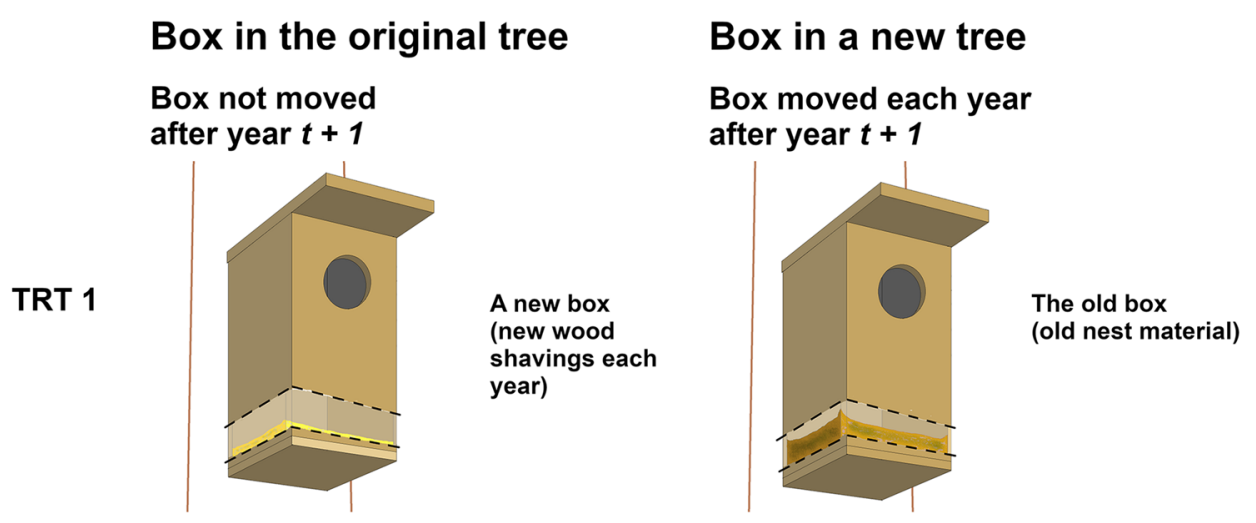

\section{Successful nesting in year $t$}

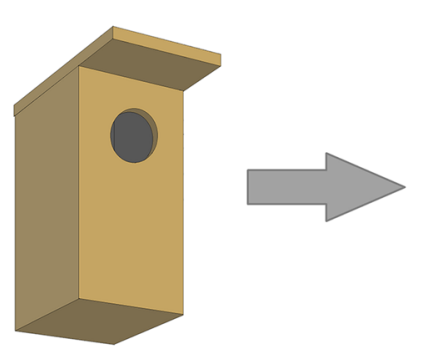

TRT 2
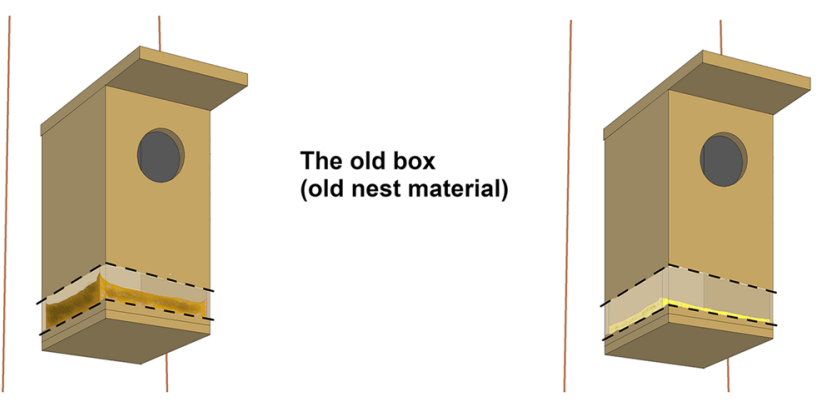

\section{A new box (new wood shavings each year)}

TRT 3
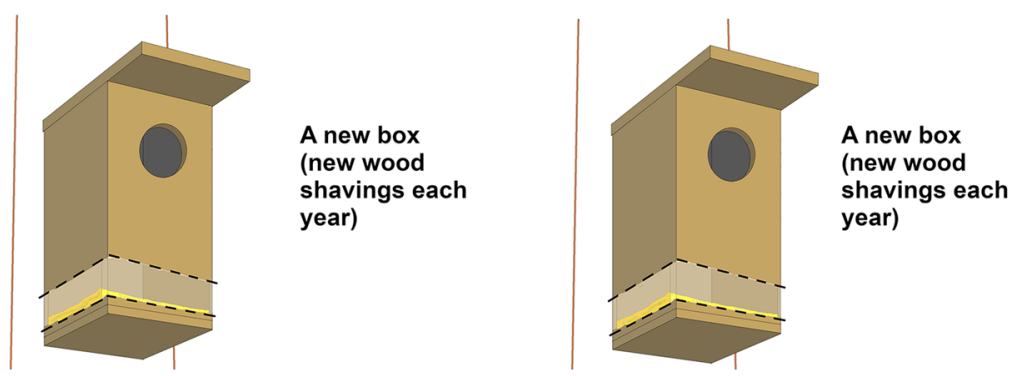

Fig. 1 The experimental procedure following a successful nesting consisted of three treatments (TRT) to provide the Boreal Owls with two options each nesting season; a box containing new wood shavings in the original nest tree vs. a box containing old nest material from the successful nesting in a new tree for the season (TRT 1); a box containing old nest material from the successful nesting in the original nest tree vs. a box containing new wood shavings in the new tree for the season (TRT 2); and a box containing new wood shavings in both the original nest tree and a new tree for the season (TRT 3) 
nesting by Boreal Owls in the following season (year $n+1$ ), the original box was relocated once more to a further new tree, and the wood shavings in the box on the original nest tree was renewed, between September (in year $n+1$ ) and April (in year $n+2$ ). I repeated this procedure each year until Boreal Owls nested in one of the two boxes. In this way, Boreal Owls always had the choice between the box with the old nest material in a new tree for the season, and a box lined with new wood shavings in the original tree (Fig. 1). The information conveyed by the content of the boxes was thus opposite to and in conflict with the information in a natural situation, where new cavities without old nest material appear at new sites as a supplement to old ones with old nest material still present.

In treatment 2, the box in which Boreal Owls had nested successfully (in year $n$ ) was left in place with its content of old nest material, and a new one was installed in another tree, between September (in year $n$ ) and April (in year $n+1$ ). If none of the two boxes were used for nesting by Boreal Owls in the following season (year $n+1$ ), the new box was relocated, and its content of wood shavings renewed, between September (in year $n+1$ ) and April (in year $n+2$ ). I repeated this procedure each year until Boreal Owls nested in one of the two boxes. In this way, Boreal Owls always had the choice between a box lined with new wood shavings in a new tree for the season, and the box with the old nest material in the original tree (Fig. 1). The information conveyed by the content of the boxes was thus the same as in a natural situation.

In treatment 3, the box in which Boreal Owls had nested successfully (in year $n$ ) was exchanged with a new one, and another new box was installed in another tree, between September (in year $n$ ) and April (in year $n+1$ ). If none of the two boxes were used for nesting by Boreal Owls in the following season (year $n+1$ ), the new box in the new tree was relocated, and the wood shavings in both boxes renewed, between September (in year $n+1$ ) and April (in year $n+2$ ). I repeated this procedure each year until Boreal Owls nested in one of the two boxes. In this way, Boreal Owls always had the choice between a box lined with new wood shavings in a new tree for the season, and a box lined with new shavings in the original tree (Fig. 1). The information conveyed by the content of the boxes was thus in conflict with the information in a natural situation, and provided no cues to the owls for selection of nest site.

I relocated and installed the boxes when time allowed between September and April. In all treatments, I installed the spatially new box in the same species of tree as the original nest tree and in a habitat as similar as possible, and made sure that it could not be seen from its previous position or from the box in the original tree. These constraints defined the distance between the two boxes in the dyad, which ranged 40-600 $\mathrm{m}$ when box selection occurred (see below).
In comparison, available cavities made by the Black Woodpecker in southeastern Norway occurred at a density of c. 2 per $\mathrm{km}^{2}$ (Rolstad et al. 2000), which corresponds to an average distance of c. $800 \mathrm{~m}$ between cavities. The two available boxes at a locality had identical measures and differed only in their spatial position and content.

A box was defined as being selected when at least one Boreal Owl egg had been laid there. In some cases, the box that was not selected by Boreal Owls became occupied by another bird species. Three of these cases were excluded from the analyses because there was doubt as to whether the Boreal Owl made its selection first, and thus whether both boxes were available when the owl initiated breeding. The number of cases used in the analysis was 34, 31 and 13 in treatments 1, 2 and 3, respectively. These 78 cases were from 42 different localities.

At each locality, I usually conducted treatment 1 first (mean rank \pm SE $1.2 \pm 0.1$ ), thereafter treatment 2 (mean rank $1.7 \pm 0.1$ ), and finally treatment 3 (mean rank $2.3 \pm 0.3$ ). This order of treatments was used because I regarded treatment 1 as the radical one, differing most from the natural pattern reflected in treatment 2 , whereas I regarded treatment 3 as the control. Treatment 1 produced conflicting information for the Boreal Owls (cf. Schmidt et al. 2010), while treatment 3 mimicked the situation where boxes are cleaned out after the breeding season (cf. Møller 1989, 1994). Because the order of treatments was not randomized, I corrected for it in the statistical analysis (see below).

If the owls selected the box in a new tree and nested successfully, this tree became the original tree in the next treatment. The box in the former original tree was then removed. If the owls' nest was depredated or deserted, the boxes were left in place until a successful nesting took place in one of them. Then the experiment continued as described above. If all nesting attempts by Boreal Owl in this study had been successful, four nesting attempts at one locality would have been sufficient for all three treatments to be performed there. However, due to frequent nest predation (cf. Sonerud 1985a, 1993) and to occasional nest desertion, at most locations more than $n+1$ nesting attempts were needed to perform $n$ treatments.

With increasing rank in the order of treatments, there was no significant change in either the number of nesting seasons that a box had been present in the original nest tree $\left(F_{2,75}=0.46, p=0.63\right)$, the number of years elapsed since the successful nesting $\left(F_{2,75}=0.36, p=0.70\right)$, or the distance between the two boxes $\left(F_{2,75}=0.13, p=0.87\right)$.

\section{Identity, age and residential status of the owls}

To be able to test if the residential status or age of an owl affected its selection of nest box, I made effort to capture the breeding owls at both the pre-treatment and the treatment 
nest. Males were captured in mist nets or a swing-door trap when delivering prey to nestlings, while most females were captured by hand when incubating or brooding. The male was captured at both nests in 50 of the 78 cases. I defined resident males as those that had previously nested successfully at the same locality ( 9 cases) or in a neighbor territory (3 cases), and immigrant males as those that did not wear a band when captured at the treatment nest at localities where the male at the associated pre-treatment nest had been captured and banded ( 38 cases). In the remaining 28 cases, the male had unknown identity, either because it was not captured at the treatment nest (23 cases), or because it did not wear a band when captured at the treatment nest at localities where the male at the pre-treatment nest had not been captured ( 5 cases). The female was captured at both the pre-treatment and the treatment nest in 59 of the 78 cases. Only two of these females had nested at the same locality previously. Two others had been banded $>50 \mathrm{~km}$ away, and these as well as the 55 females that did not wear a band when captured were defined as immigrants.

I aged captured owls from the molting pattern of the primaries (Hörnfeldt et al. 1988; Sonerud GA, personal observation). For the purpose of the present study, the owls were scored as young ( $\leq 2 \mathrm{yrs}$, i.e., $2-3 \mathrm{CY})$ or old $(\geq 3$ yrs, i.e., $\geq 4 \mathrm{CY}$ ). Of the 55 males that were captured at the treatment nest, 32 were scored as young and 23 as old. Of the 62 females that were captured at the treatment nest, 30 were scored as young and 32 as old. The reason for pooling 1 -year-old owls and 2-year-old owls as young was that only 4 of the males (7\%) and 11 of the females (18\%) were scored as 1 year old. This is a lower proportion than Hörnfeldt et al. (1990) and Laaksonen et al. (2002) found in northern Sweden and in Finland, respectively.

The proportion of the nesting males that I classified as residents was higher among those scored as old than among those scored as young ( $41 \%$ vs. $11 \%, \chi^{2}=6.27, d f=1$, $p=0.012$ ). Thus, I used the age of the owls as a proxy of their residential status.

Nest predation was the most important reason that not all adult owls were captured. Because almost all cases of nest predation occurred during incubation (cf. Sonerud 1985a), and because I for ethical reasons did not attempt to trap males before hatching, no males from depredated nests were captured.

\section{Pine Marten abundance}

An epizootic of sarcoptic mange among Red Foxes spread from central Norway to the whole country during 1976-1986, resulting in a severe decline of the Red Fox population (Smedshaug et al. 1999). This lead to an increase in the hunting bag of Pine Marten (Smedshaug et al. 1999), probably caused by relaxed competition with and predation by the Red Fox (Storch et al. 1990; Lindström et al. 1995). In my study area, the peak effect of the Red Fox reduction on the harvest of Pine Marten was reached around 1990 (Smedshaug et al. 1999). Thereafter, the Red Fox population recovered (Selås 1998, cf. Breisjøberget et al. 2018), and hunting bags of its prey species, including the Pine Marten, decreased (Selås 1998, see below).

Pöysä et al. (2016) found that depredation of goldeneye nests by Pine Marten in the boreal forest of Finland was independent of the short-term multi-annual fluctuation in microtine rodent abundance, and suggested that this may be due to individual martens learning the nest box locations. However, long-term changes in the population density of Pine Marten, such as those caused by the reduction of the Red Fox population due to sarcoptic mange (see above), may affect the probability of depredation on Boreal Owl nests, and thereby nest site selection. To control for this factor, I extracted data on Pine Marten hunting bags from Statistics Norway (2020) for my study period.

Smedshaug et al. (1999) and Statistics Norway (2020) describe in detail how these data are compiled from the hunters' reports. The Pine Marten hunting bag from one season consists of all animals harvested from 1 November in year $n-1$ until 15 March in year $n$. Among the Pine Martens harvested, most are trapped and few shot. On the national level, data are available for all 23 years of my study, and in these years, the annual hunting bag ranged 3187-11,300, with median 6150. On the regional level, data are available for a shorter period, for Hedmark county, from 1992 and onwards, i.e., for 16 of the years of my study, and in these years, the annual hunting bag ranged 320-960, with median 400. There was a fairly good association between the annual marten harvest number on the regional level and the national level $\left(R^{2}=0.39, n=16\right)$. To cover as much as possible of my data on selection of nest tree by Boreal Owls, I, therefore, used the national series on Pine Marten harvest.

I was interested in the long-term effect of Pine Marten abundance. To minimize the effect of any short-term variation in marten harvest from year to year of no interest to my study (see above), I used the 5 years running mean of the marten harvest data on the national level as proxy for the long-term change in the Pine Marten population density in my study area, centered on the last winter before the Boreal Owl selected a nest tree. For a Boreal Owl nest tree selection in year $n$, I assigned the mean of the national hunting bag of Pine Marten from the trapping season ending two years prior to the selection of nest tree (November in year $n-3$-March in year $n-2$ ) to the trapping season ending two years after the selection of nest tree (November in year $n+1$-March in year $n+2$ ). For the years that Boreal Owls selected one of the nest boxes in a dyad, this running mean ranged 3614-9934, with median $5488(n=16)$. 


\section{Spatial independence of data}

Brainerd (1997) found that the average home range of Pine Martens at $60^{\circ} \mathrm{N}$ in Norway and Sweden was $7 \mathrm{~km}^{2}$, which corresponds to a circle with a diameter of c. $3 \mathrm{~km}$. To compare this distance with the spatial scale of my study, I calculated the nearest neighbor distance (NND) for localities where an experimental box was selected. This distance decreased with increasing number of years allowed between box selection at the two locations regarded as nearest neighbors $\left(F_{1,76}=3.98, p=0.050\right)$. First, restricting the data to localities where box selection occurred the same year $(n=76)$, NND was on average \pm SE $18.2 \pm 2.1$ (range 2-90) $\mathrm{km}$, with a median of $12 \mathrm{~km}$ and a $10 \%$ percentile of $3 \mathrm{~km}$. Thus, almost all cases of box selection within the same year were sufficiently spatially separated to be located in different Pine Marten home ranges. Second, NND irrespective of the year when nest box selection occurred $(n=78)$ was on average $4.2 \pm 0.4$ (range $1-25$ ) $\mathrm{km}$, with a median of $3 \mathrm{~km}$. In this case, the time difference between cases of box selection at nearest neighbor localities was on average $2.6 \pm 0.3$ (range $0-11)$ years, with a median of 2 years. Thus, disregarding the year in which box selection took place, only half the cases were sufficiently spatially separated to be in different Pine Marten home ranges. However, given that these cases were separated in time with up to 11 years, an age reached only by a few Pine Martens (Marchesi 1989), probably most of the cases were associated with different Pine Marten individuals. Thus, the risk of committing pseudoreplication was quite small.

\section{Sample size}

I used one case in one treatment as unit in statistical tests. Among the 50 males and 59 females trapped at both the pretreatment and the treatment nest, two males, but no female, were involved in two treatments. Thus, among the 28 cases in which identifying the male in both the pre-treatment and the treatment nest had failed, I would expect one male to be involved in more than one treatment. It might be argued that the pattern of nest site selection found is biased using each case in a treatment as unit in statistical tests, because such an approach might violate the assumption of statistical independence, and inflate sample size. However, if the intraindividual variation can be demonstrated to be at least as large as the inter-individual variation, pooling observations will not bias the results or increase the probability of making a type I error (Leger and Didrichsons 1994). Because the two males known to be involved in two treatments selected the box in the original tree in treatment 1 and the box in the new tree in treatment 2 , including both cases with these males would not have biased the results or increased the probability of making a type I error (Leger and Didrichsons
1994). Hence, weighing the risk of pseudoreplication against reduction in sample size, I decided to include data from both treatments in both cases.

\section{Data analysis}

The data on the owls' selection of nest box were binomial and analyzed using logistic regression in $\mathrm{JMP}^{\circledR}$ Pro version 15.0.0 (SAS 2012).

For each case of box selection, I measured the following explanatory variables: (1) number of years since the successful nesting (1-12); (2) number of nesting seasons a box had been present in the original nest tree (2-20); (3) distance between the two available boxes at the locality, recorded after fledging by pacing both ways, averaged, and truncated down to the nearest $10 \mathrm{~m}(40-600 \mathrm{~m})$; (4) time elapsed from the day the boxes were relocated to the day the first egg was laid (10-229 days); (5) age of the breeding male; and (6) age of the breeding female. Variables (1) and (2) were alternative proxies for the temporal exposure of a cavity in the original nest tree to the Pine Marten, and were not included in the same models because they were highly correlated $\left(R^{2}=0.34\right)$. All other correlations between the variables $(1-4)$ were negligible $\left(R^{2} \leq 0.01\right)$. Variable (4) was included in all models of box selection to control for the time available for the owls to decide among the options.

In each model tested, continuous variables were standardized. I provide parameter estimates calculated by Wald test. Estimates are given with $\pm 1 \mathrm{SE}$.

\section{Results}

\section{Selection of nest tree}

Overall, the probability that the owls would select the new nest tree increased with number of years elapsed since the successful nesting in the original tree, independent of treatment [Table 1a, Fig. 2, Electronic Supplementary Material (ESM) Appendix 1]. There was no significant effect of the interaction between time elapsed and treatment when added to the model in Table 1a $\left(\chi^{2}=0.58, d f=2, p=0.75\right)$. Compared with the selection of nest tree in treatment 3 (62\% of cases in the new tree), the owls were less likely to select the new tree in treatment 1 ( $21 \%$ of cases in the new tree), and more likely to select the new tree in treatment $2(87 \%$ of cases in the new tree). Thus, compared with the cases when the information conveyed by the content of the boxes provided no cues to the owls for selection of nest site (treatment 3), the owls were less likely to select the new tree when the information conveyed by the content of the boxes was opposite to and in conflict with that in a natural situation (treatment 1), and more likely to select the new tree when 
Table 1 The effect of measured variables on the probability that Boreal Owls selected a new nest tree rather than the original nest tree in nest box relocation treatments

\begin{tabular}{|c|c|c|c|c|}
\hline & Estimate $\pm \mathrm{SE}$ & $\chi^{2}$ & $d f$ & $p$ \\
\hline \multicolumn{5}{|l|}{ a) } \\
\hline Intercept & $0.46 \pm 0.53$ & 0.75 & & 0.39 \\
\hline Treatment & & 15.44 & 2 & 0.0004 \\
\hline Treatment 1 vs. 3 & $-2.38 \pm 0.66$ & 12.96 & & 0.0003 \\
\hline Treatment 2 vs. 3 & $1.86 \pm 0.67$ & 7.98 & & 0.0059 \\
\hline Time since nesting in original tree & $1.53 \pm 0.55$ & 7.68 & 1 & 0.0056 \\
\hline Distance between boxes & $0.33 \pm 0.36$ & 0.88 & 1 & 0.35 \\
\hline Pine marten abundance & $0.23 \pm 0.41$ & 0.30 & 1 & 0.58 \\
\hline Time since box relocation & $0.41 \pm 0.35$ & 1.35 & 1 & 0.24 \\
\hline Rank in the order of treatments & & 0.15 & 2 & 0.93 \\
\hline Rank 2 vs. 1 & $0.38 \pm 1.00$ & 0.14 & & 0.70 \\
\hline Rank 3 vs. 2 & $-0.42 \pm 1.51$ & 0.08 & & 0.78 \\
\hline \multicolumn{5}{|l|}{ b) } \\
\hline Intercept & $0.30 \pm 0.57$ & 0.28 & & 0.60 \\
\hline Treatment & & 12.99 & 2 & 0.0015 \\
\hline Treatment 1 vs. 3 & $-1.80 \pm 0.59$ & 9.42 & & 0.0021 \\
\hline Treatment 2 vs. 3 & $2.39 \pm 0.79$ & 9.19 & & 0.0024 \\
\hline Time with box present in original tree & $1.95 \pm 0.61$ & 10.33 & 1 & 0.0013 \\
\hline Distance between boxes & $0.67 \pm 0.38$ & 3.19 & 1 & 0.074 \\
\hline Pine marten abundance & $0.38 \pm 0.41$ & 0.86 & 1 & 0.35 \\
\hline Time since box relocation & $0.34 \pm 0.37$ & 0.81 & 1 & 0.37 \\
\hline Rank in the order of treatments & & 0.15 & 2 & 0.93 \\
\hline Rank 2 vs. 1 & $-0.05 \pm 1.08$ & $<0.01$ & & 0.97 \\
\hline Rank 3 vs. 2 & $1.12 \pm 1.56$ & 0.52 & & 0.47 \\
\hline
\end{tabular}

The owls could select between the box in the original tree (where the last nesting was successful by experimental design) and a box in a new tree for the season, with (a) the exposure of the cavity in the original nest tree to the Pine Marten taken as number of years elapsed since the successful nesting there, and (b) the exposure of the cavity in the original nest tree to the Pine Marten taken as number of nesting seasons a box had been present there. Logistic regression models with parameter estimates from the Wald test based on standardized continuous variables. Treatment denotes the three treatment types (see text) and Rank denotes whether the treatment type was the first, second or third performed at the locality. Treatment and Rank contrasts different levels with a reference level. Time since nesting in the original tree ranged 1-12 years, number of nesting seasons a box had been present in the original tree ranged 2-20, distance between the two available nest boxes ranged 40-600 $\mathrm{m}$, and time elapsed between nest box relocation and onset of egg laying ranged 10-229 days. Whole model $(n=78)$ : a $\chi^{2}=45.29, d f=8, p<0.0001, R^{2}=0.42$, model fit $\chi^{2} / d f=0.90$. b $\chi^{2}=49.70, d f=8, p<0.0001, R^{2}=0.46$, model fit $\chi^{2} / d f=0.84$ the information conveyed by the content of the boxes was as in a natural situation (treatment 2).

There was no significant effect of distance between the two boxes, Pine Marten abundance, or time elapsed from the day the boxes were relocated to the day the first egg was laid (Table 1a). The effect of rank order of treatments was negligible (Table 1a).

The results were very similar when the exposure of the cavity in the original nest tree to the Pine Marten was taken as number of nesting seasons a box had been present there rather than time elapsed since the successful nesting there; the probability that the owls would select the new nest tree increased with number of nesting seasons a box had been present there, independent of treatment (Table 1b). The only notable difference was that the effect of distance between the boxes became marginally non-significant (Table 1b); the probability that the owls would select the new nest tree tended to increase with increasing distance from the original nest tree.

In a model including only treatment, time since the successful nesting in the original nest tree, and rank in the order of treatments, in treatment 1 (conflicting information conveyed by the content of the boxes) the predicted switch from selecting the original tree to selecting the new tree, i.e., when the probability of either was 0.50 , occurred when approximately 5 years $(5.2,4.7$ and 5.0 for rank 1, 2 and 3 , respectively) had elapsed since the successful nesting in the original tree. The corresponding figure in treatment 3 (no information conveyed by the content of the boxes) was 1-2 years (1.6, 1.1 and 1.4 for rank 1, 2 and 3, respectively), 


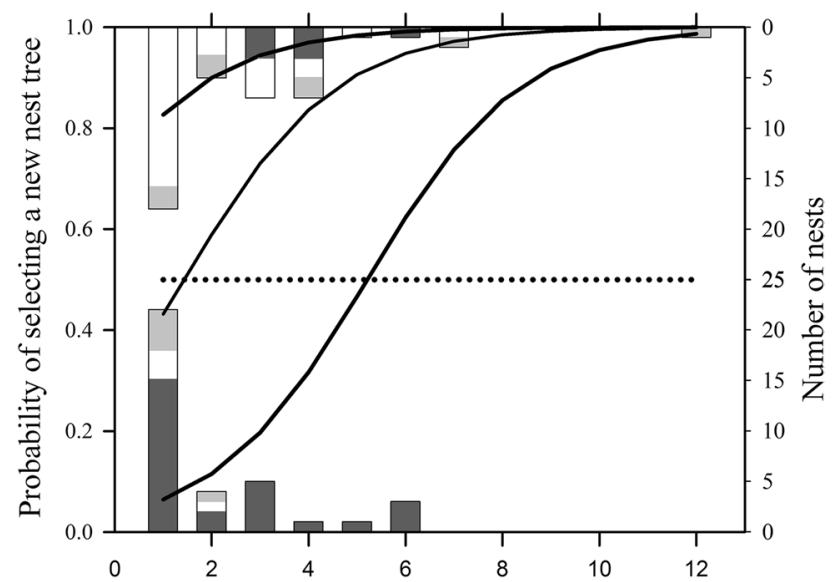

Time since successful nesting in original tree (years)

Fig. 2 The probability that Boreal Owls selected the box in a new nest tree rather than the box in the original nest tree as function of treatment and number of years elapsed since the successful nesting in the original nest tree, with the curves describing the predictions from the logistic regression model. See Fig. 1 for explanation of treatments. The upper curve denotes treatment 2 (natural information conveyed by box content), the middle curve denotes treatment 3 (no information conveyed by box content), and the lower curve denotes treatment 1 (conflicting information conveyed by box content). The bars show the raw data and denote the distribution of cases in which the owls selected the new nest tree (upper row) and the original nest tree (lower row), with white part representing cases of treatment 2 , grey parts representing cases of treatment 3 , and black parts representing cases of treatment 1 . The dotted horizontal line indicates random selection. For simplicity, the negligible effect of rank in the order of treatments is disregarded

while the model predicted the new tree to always be selected ( $-1.1,-1.6$ and -1.3 years for rank 1,2 and 3 , respectively) in treatment 2 (information as in a natural situation conveyed by the content of the boxes). In a model without the rank in the order of treatments, thus disregarding its negligible effect, the predicted switch occurred when 5.2, 1.4 and -1.5 years had elapsed since the successful nesting in the original tree, respectively, in treatments 1,3 and 2 (Fig. 2).

\section{Pattern of selection by old and young owls}

Whether the male was scored as resident or immigrant did not affect the selection of nest tree (ESM Appendix 2). Similarly, whether the male was the same individual as the previous male nesting at the same locality or another male did not affect the selection of nest tree (ESM Appendix 3). In both cases, including the variable scoring male identity decreased the sample size from 78 to 50 , but did not qualitatively change the effects of the other variables (Table 1 vs. ESM Appendixes 2 and 3).

The age of the male significantly affected the selection of nest tree (Table 2). Males scored as old were more likely to select the box in the new tree than were young males (Table 2). Although including this variable decreased the sample size from 78 to 55 , the effects of the other variables did not qualitatively change (Table 1 vs. Table 2). In contrast, the variable expressing female age did not significantly affect the selection of nest tree, neither when included without the variable expressing male age $(n=62$, ESM Appendix 4) nor when included together with the variable expressing male age $(n=53$, ESM Appendix 5). Male age had still a significant effect when included together with female age (ESM Appendix 5).

When adding the interaction with male age for one variable at a time in the model in Table $2 b$, no interaction had a significant effect, but the interaction between male age and time with box present in the original nest tree was marginally non-significant $\left(\chi^{2}=3.03, d f=1, p=0.082\right)$. Keeping only the variables with significant effect in Table $2 b$ (treatment, time with box present in the original nest tree, distance between the two available boxes at the locality, and male age), the interaction between male age and time with box present in the original nest tree became significant $\left(\chi^{2}=4.08, d f=1, p=0.043\right)$.

For further analyses of selection of nest tree by old and young males separately, the number of cases were too few for separating between the three treatments. I, therefore, pooled treatments to two alternatives; either the box in the original nest tree containing new wood shavings (treatments 1 and 3 pooled) or not (treatment 2), or the box in the new tree for the season containing new wood shavings (treatments 2 and 3 pooled) or not (treatment 1). In both cases, for old males, there was no effect of treatment, distance between the two boxes, or Pine Marten abundance, whereas the effect of number of nesting seasons a box had been present in the original nest tree was marginally non-significant; the probability that the owls would select the box in the new tree for the season tended to increase with number of nesting seasons a box had been present in the original nest tree (Table 3). A corresponding analysis when the exposure of the cavity in the original nest tree to the Pine Marten was taken as time elapsed since the successful nesting in the original nest tree was impossible because all cases of selection of the box in the original tree occurred one year after the successful nesting there (see below). For young males whether the box in the original nest tree contained new wood shavings (treatments 1 and 3 pooled) or not (treatment 2), only treatment had a significant effect (Table 4), whereas there was no significant effect of time elapsed since the successful nesting in the original nest tree (Table $4 \mathrm{a}$ ) or number of nesting season a box had been present in the original nest tree (Table 4b). For the box in the new tree for the season containing new wood shavings (treatments 2 and 3 pooled) or not (treatment 1), a corresponding analysis was impossible because 
Table 2 The effect of measured variables on the probability that aged Boreal Owl males selected a new nest tree rather than the original nest tree in nest box relocation treatments

\begin{tabular}{|c|c|c|c|c|}
\hline & Estimate $\pm \mathrm{SE}$ & $\chi^{2}$ & $d f$ & $p$ \\
\hline \multicolumn{5}{|l|}{ a) } \\
\hline Intercept & $-2.01 \pm 1.14$ & 3.13 & & 0.077 \\
\hline Treatment & & 8.54 & 2 & 0.014 \\
\hline Treatment 1 vs. 3 & $-4.27 \pm 1.57$ & 7.35 & & 0.0067 \\
\hline Treatment 2 vs. 3 & $2.29 \pm 1.21$ & 3.59 & & 0.058 \\
\hline Time since nesting in original tree & $4.33 \pm 1.66$ & 6.82 & 1 & 0.0090 \\
\hline Distance between boxes & $0.87 \pm 0.61$ & 2.05 & 1 & 0.15 \\
\hline Pine marten abundance & $0.60 \pm 0.75$ & 0.64 & 1 & 0.42 \\
\hline Time since box relocation & $1.20 \pm 0.66$ & 3.32 & 1 & 0.069 \\
\hline Rank in the order of treatments & & 3.98 & 2 & 0.14 \\
\hline Rank 2 vs. 1 & $3.64 \pm 1.82$ & 3.97 & & 0.046 \\
\hline Rank 3 vs. 2 & $-2.53 \pm 2.85$ & 0.79 & & 0.38 \\
\hline Male age (old vs. young) & $4.33 \pm 1.66$ & 6.92 & 1 & 0.0085 \\
\hline \multicolumn{5}{|l|}{ b) } \\
\hline Intercept & $-1.34 \pm 0.90$ & 2.23 & & 0.14 \\
\hline Treatment & & 7.11 & 2 & 0.029 \\
\hline Treatment 1 vs. 3 & $-2.43 \pm 1.00$ & 5.93 & & 0.015 \\
\hline Treatment 2 vs. 3 & $1.53 \pm 0.92$ & 2.77 & & 0.096 \\
\hline Time with box present in original tree & $2.74 \pm 1.06$ & 6.69 & 1 & 0.0097 \\
\hline Distance between boxes & $1.28 \pm 0.64$ & 3.97 & 1 & 0.046 \\
\hline Pine marten abundance & $0.34 \pm 0.66$ & 0.27 & 1 & 0.60 \\
\hline Time since box relocation & $0.85 \pm 0.64$ & 1.78 & 1 & 0.18 \\
\hline Rank in the order of treatments & & 0.91 & 2 & 0.63 \\
\hline Rank 2 vs. 1 & $1.15 \pm 1.30$ & 0.78 & & 0.38 \\
\hline Rank 3 vs. 2 & $-0.43 \pm 2.30$ & 0.04 & & 0.85 \\
\hline Male age (old vs. young) & $3.46 \pm 1.42$ & 5.92 & 1 & 0.015 \\
\hline
\end{tabular}

The owls could select between the box in the original tree (where the last nesting was successful by experimental design) and a box in a new tree for the season, with (a) the exposure of the cavity in the original nest tree to the Pine Marten taken as number of years elapsed since the successful nesting there, and (b) the exposure of the cavity in the original nest tree to the Pine Marten taken as number of nesting seasons a box had been present there. Logistic regression models with parameter estimates from the Wald test based on standardized continuous variables. Treatment denotes the three treatment types (see text) and Rank denotes whether the treatment type was the first, second or third performed at the locality. Treatment and Rank contrasts different levels with a reference level. Time since nesting in the original tree ranged 1-12 years, number of nesting seasons a box had been present in the original tree ranged 2-20, distance between the two available nest boxes ranged 40-600 $\mathrm{m}$, and time elapsed between nest box relocation and onset of egg laying ranged 15-229 days. Whole model $(n=55)$ : a $\chi^{2}=49.21, d f=9, p<0.0001, R^{2}=0.65$, model fit $\chi^{2} / d f=0.60$. b $\chi^{2}=45.83, d f=9, p<0.0001, R^{2}=0.60$, model fit $\chi^{2} / d f=0.67$ the young owls always selected the original nest tree in treatment 1 (see below).

When old males selected the box in the original nest tree ( 8 cases), the successful nesting there had always taken place the year before. When old males selected the box in a new tree (15 cases), time elapsed since the successful nesting in the original tree was 1 year in 6 cases, 2 years in 2 cases, and ranged up to 7 years in the remaining 7 cases (mean $2.7 \pm 0.5$ years, median 2 years). Thus, the switch from selecting the original tree to selecting the new tree occurred when only 2 years had elapsed since the successful nesting in the original tree. The old males were significantly more likely to select the box in the new tree for the season than the box in the original nest tree when 2 or more years had elapsed since the successful nesting in the original tree than when only 1 year had elapsed ( 1.00 vs. $0.43 ; \chi^{2}=7.89$, $d f=1, p=0.0050)$.

All young males in treatment 1 selected the box lined with new wood shavings in the original tree (16 cases), all but one in treatment 2 selected the box lined with new wood shavings in the new tree ( 9 cases), while in treatment 3 when both alternative boxes were lined with new wood shavings, four selected the original tree and three selected the new tree. In fact, in all cases but one the young males selected a box lined with new content. Young males thus seemed to base their selection of nest tree on the information 
Table 3 The effect of measured variables on the probability that old Boreal Owl males (3 years or older) selected a new nest tree rather than the original nest tree in nest box relocation treatments

\begin{tabular}{lrlll}
\hline & Estimate \pm SE & $\chi^{2}$ & $d f$ & $p$ \\
\hline a) & & & & \\
Intercept & $2.12 \pm 1.33$ & 2.53 & & 0.11 \\
Treatment & $-1.03 \pm 1.01$ & 1.05 & 1 & 0.31 \\
Time with box in original tree & $3.55 \pm 2.02$ & 3.07 & 1 & 0.080 \\
Distance between boxes & $2.07 \pm 1.29$ & 2.58 & 1 & 0.11 \\
Pine marten abundance & $-1.53 \pm 1.41$ & 1.18 & 1 & 0.28 \\
b) & & & & \\
Intercept & $2.10 \pm 1.34$ & 2.42 & & 0.12 \\
Treatment & $-1.03 \pm 1.00$ & 1.06 & 1 & 0.30 \\
Time with box in original tree & $3.52 \pm 2.05$ & 2.94 & 1 & 0.087 \\
Distance between boxes & $2.06 \pm 1.30$ & 2.50 & 1 & 0.11 \\
Pine marten abundance & $-1.51 \pm 1.43$ & 1.12 & 1 & 0.29 \\
\hline
\end{tabular}

The owls could select between the box in the original tree (where the last nesting was successful by experimental design) and a box in a new tree for the season, and the exposure of the cavity in the original nest tree to the Pine Marten taken as number of nesting seasons a box had been present there, with (a) the box in the original nest tree containing new wood shavings (treatments 1 and 3 pooled) or not (treatment 2), and (b) the box in the new tree for the season containing new wood shavings (treatments 2 and 3 pooled) or not (treatment 1 ). Logistic regression models with parameter estimates from the Wald test based on standardized continuous variables. Number of nesting seasons a box had been present in the original tree ranged $2-8$, and distance between the two available nest boxes ranged $40-440 \mathrm{~m}$. The low sample size precluded inclusion of time elapsed since nest box relocation and rank in the order of treatments. Whole model $(n=23)$ : a $\chi^{2}=20.05, d f=4, p=0.0005, R^{2}=0.67$, model fit $\chi^{2} / d f=0.54$. b $\chi^{2}=20.06, d f=4, p=0.0005, R^{2}=0.67$, model fit $\chi^{2} / d f=0.54$

conveyed by the content of the box rather than on the position of the box. The distribution of the selected boxes on nest tree differed significantly between treatments 1 and 2 for young males $\left(\chi^{2}=20.92, d f=1, p<0.0001\right)$, but not for old males $\left(\chi^{2}=2.65, d f=1, p=0.10\right)$. Further, while young males selected a box with the old nest material in only 1 of 25 cases in treatments 1 and 2, old males did so in 7 of 21 cases $\left(\chi^{2}=7.38, d f=1, p=0.0089\right)$.

\section{Breeding success in relation to nest box content}

I tested whether the old nest material from the original nesting had any effect on the breeding performance of the owls in non-depredated nests by comparing the cases when the owls selected the box containing old nest material from the original nesting with the nearest recorded neighbor Boreal Owl nest the same year in a box containing new wood shavings (not necessarily a dyad box). The distance between the two nests compared ranged $3.9-18.0 \mathrm{~km}$, with an average of $8.3 \pm 1.3 \mathrm{~km}(n=10)$. There was no significant difference between these two
Table 4 The effect of measured variables on the probability that young Boreal Owl males (1 or 2 years old) selected a new nest tree rather than the original nest tree in nest box relocation treatments

\begin{tabular}{lrrll}
\hline & Estimate \pm SE & $\chi^{2}$ & $d f$ & $p$ \\
\hline a) & & & \\
Intercept & $-1.06 \pm 1.07$ & 0.97 & 0.32 \\
Treatment & $-2.89 \pm 1.26$ & 5.29 & 1 & 0.022 \\
Time since nesting in original & $1.73 \pm 1.59$ & 1.18 & 1 & 0.28 \\
$\quad$ tree & & & \\
Distance between boxes & $0.28 \pm 0.97$ & 0.08 & 1 & 0.77 \\
Pine marten abundance & $0.36 \pm 1.18$ & 0.09 & 1 & 0.76 \\
Time since box relocation & $-0.39 \pm 0.82$ & 0.22 & 1 & 0.64 \\
Rank in the order of treatments & & 2.25 & 2 & 0.32 \\
$\quad$ Rank 2 vs. 1 & $2.64 \pm 2.12$ & 1.55 & 0.21 \\
$\quad$ Rank 3 vs. 2 & $0.57 \pm 2.49$ & 0.05 & 0.82 \\
b) & & & \\
Intercept & $-0.96 \pm 1.02$ & 0.89 & 0.35 \\
Treatment & $-2.23 \pm 1.01$ & 4.89 & 1 & 0.027 \\
Time with box in original tree & $1.38 \pm 1.28$ & 1.15 & 1 & 0.28 \\
Distance between boxes & $0.54 \pm 0.94$ & 0.34 & 1 & 0.56 \\
Pine marten abundance & $-0.03 \pm 1.05$ & $<0.01$ & 1 & 0.97 \\
Time since box relocation & $-0.48 \pm 0.47$ & 0.39 & 1 & 0.53 \\
Rank in the order of treatments & & 1.952 & 0.38 \\
Rank 2 vs. 1 & $1.91 \pm 1.83$ & 1.08 & 0.30 \\
Rank 3 vs. 2 & $0.58 \pm 2.60$ & 0.05 & 0.82 \\
\hline
\end{tabular}

The owls could select between the box in the original tree (where the last nesting was successful by experimental design) and a box in a new tree for the season, and the box in the original nest tree contained new wood shavings (treatments 1 and 3 pooled) or not (treatment 2), with (a) the exposure of the cavity in the original nest tree to the Pine Marten taken as number of years elapsed since the successful nesting there, and (b) the exposure of the cavity in the original nest tree to the Pine Marten taken as number of nesting seasons a box had been present there. Logistic regression models with parameter estimates from the Wald test based on standardized continuous variables. Treatment denotes the three treatment types (see text) and Rank denotes whether the treatment type was the first, second or third performed at the locality. Treatment and Rank contrasts different levels with a reference level. Time since nesting in the original tree ranged 1-12 years, number of nesting seasons a box had been present in the original tree ranged 2-20, distance between the two available nest boxes ranged 50-600 m, and time elapsed between nest box relocation and onset of egg laying ranged $15-229$ days. Whole model $(n=32)$ : a) $\chi^{2}=25.55$, $d f=7, p=0.0006, R^{2}=0.62$, model fit $\chi^{2} / d f=0.65$. b) $\chi^{2}=23.91$, $d f=7, p=0.0012, R^{2}=0.58$, model fit $\chi^{2} / d f=0.72$

groups (Wilcoxon's signed-ranks pair-wise test) for date of first egg $(52.5 \pm 5.7$ vs. $56.0 \pm 4.5$ days after 1 March, $n=10$ box pairs, $p=0.44)$, number of eggs laid $(4.7 \pm 0.5$ vs. $4.8 \pm 0.3, n=6$ box pairs, $p=0.74)$, or number of young fledged ( $2.6 \pm 0.7$ vs. $2.9 \pm 0.6, n=7$ box pairs, $p=0.53$ ), whereas, as expected from the analysis above, the proportion of older males was marginally non-significantly higher among the owls that had selected the box containing old nest material than among those that had selected 
a box containing new wood shavings ( 0.86 vs. $0.43, n=7$ box pairs, $\chi^{2}=2.80, d f=1, p=0.094$ ).

\section{Discussion}

The longer time that had elapsed since the successful nesting in the original nest tree, the more likely Boreal Owls were to abandon the box in this tree and rather select the box in a new tree for nesting, independent of whether the box there contained old nest material from the original nesting or not. This pattern would tend towards minimizing the risk of nest predation. Sonerud (1985a) found a higher risk of nest predation in a cavity where the previous nesting was successful when one or more nesting seasons had elapsed without a nesting there than when the nesting occurred the year after the successful one, and attributed it to Pine Martens finding new nest boxes also at times when the boxes were not occupied by the owls, and memorizing their spatial position and including them in later foraging routes. The pattern I found in the present study, in particular in treatment 2 where the box content reflected the natural situation, supports two predictions posed by Sonerud (1985a), namely that Boreal Owls, to minimize the risk of nest predation from Pine Marten, should abandon a nest cavity even after a successful nesting, and then prefer to nest in a newly made cavity.

In addition, the Boreal Owls were more likely to select the box in a new tree for nesting the longer time a box had been present in the original nest tree, independent of whether the box there contained old nest material from the original nesting or not. This pattern would tend towards minimizing the risk of nest predation, because the risk of depredation on Boreal Owl nests in boxes had been found to increase with time since the box was installed (Sonerud 1985a, 1989, 1993).

I found that the pattern of nest tree selection differed between young and old males, but not between young and old females. This supports the suggestion from previous studies that nest site selection in the Boreal Owl depends mostly on the male (Hakkarainen and Korpimäki 1998; Hakkarainen et al. 2001).

The Boreal Owls were more likely to select a new nest tree if the box there contained new wood shavings than if it contained the old nest material from the original nesting. One explanation for this pattern may be that the owls used lack of old nest material from a previous nesting as a cue of a new cavity, which on average would expose the owls to a lower risk of nest predation than a randomly selected cavity, because the probability of nest predation increased with increasing time a box had been present in a tree (Sonerud 1985a). In fact, the younger males appeared to use the presence of new wood shavings in the box as the most important cue for selecting nest tree. The older males, in contrast, appeared to use the functional age of the cavity, i.e., how long a box had been present in the original nest tree, time elapsed since the successful nesting there, and to some extent the distance between the original nest tree and the new tree, as the most important cues, rather than box content. Thus, in the statistical models including all owls the effect of treatment type, i.e., information conveyed by box content, was mostly due to the young males, while the effects of time elapsed since the previous successful nesting in the original nest tree and since a box was first installed there, and the effect of distance between the two boxes, were mostly due to the old males. Because few Boreal Owl males in my study nested as 1 year old, most of the males scored as young ( $\leq 2$ years) in my study were probably recently settled first time nesters, and thus not very familiar with the territory at the time of nest site selection. They would, therefore, benefit from using information that was cheap to acquire as a rough cue (cf. Dall et al. 2005). Older males, on the other hand, were probably more familiar with their territory and were able to use information on the risk of nest predation that was more precise, but also more costly to acquire. Thus, the older males may have benefited most from using Bayesian updating (cf. Luttbeg 1996) of the risk of depredation at the nest site options rather than the simple WSLS rule, which underperforms compared to a Bayesian assessment rule (Chalfoun and Schmidt 2012).

How may an owl decide that a cavity should be avoided as nesting site due to high predation risk? Boreal Owl males are to a large extent locally resident after the first nesting (Löfgren et al. 1986; Korpimäki et al. 1987; Korpimäki 1993), and such local residents may attain an age of at least 11 years (Sonerud GA, personal observation). Therefore, they may monitor the turnover of cavities in their home range and be able to rank cavities according to age by memorizing when each was first encountered. A more parsimonious explanation is that the owls avoid cavities where they once have seen a Pine Marten (cf. Hakkarainen et al. 2001), or even only sensed the smell of one (cf. Amo et al. 2011), at any time of the year. Such incidences are more likely to occur with an increasing age of the cavity, because Pine Martens are more likely to visit older cavities (Sonerud 1985a). An assessment of predation risk at available cavities by regular updating of information throughout the non-breeding season may qualify as Bayesian assessment (cf. Luttbeg 1996).

One alternative explanation for the younger Boreal Owl males' avoidance of boxes with old nest material from the original nesting may be that any smell from these remains would increase the risk of nest predation by Pine Marten, as Otterbeck et al. (2019) suggested as an explanation for the higher probability of depredation in reused sparrowhawk (Accipiter nisus) nests than in new ones. However, the variable expressing whether the box contained the old nest material from the successful nesting or new wood shavings did 
not affect the probability of depredation of the Boreal Owl nests (GA Sonerud, unpublished data).

Another alternative explanation is that there may have been a poorer microclimate or a higher risk of infestation with parasites in the box with old nest material from the original nesting than in the box containing new wood shavings (cf. Møller 1989, 1994; Sumasgutner et al. 2014; Podofillini et al. 2018). Among the owls that escaped predation, however, those that had selected a box with old nest material did not raise fewer fledglings than the nearest neighbors nesting in a box with new content. Admittedly, the sample size for this comparison was very small. However, also in corresponding comparisons based on much larger samples on Eurasian Kestrels (Falco tinnunculus) in Finland and Lesser Kestrels (Falco naumanni) in Italy, birds selecting a box with old nest material did not raise fewer fledglings than birds nesting in a box with new content (Sumasgutner et al. 2014; Podofillini et al. 2018). This lack of difference should be regarded as premature, however, because it was based on the box selection made by the owls and kestrels, and not on manipulating the box content after the owls and kestrels had made their choice of nest box. Nevertheless, in altricial birds in general, there seems to be no consistent negative effect on reproductive success of selecting cavities with old nest material (Mazgajski 2007; Riding and Belthoff 2015; Diaz-Lora et al. 2019).

To test the hypothesis posed by Sonerud (1985a) that the decline in use of old boxes for breeding is a means to minimize predation risk, Korpimäki (1993) divided a population of old (10-20 years) nest boxes in Finland into four groups which were experimentally treated as follows: (i) old box remained in the original tree, (ii) old box replaced by a new box in the same tree, (iii) old box relocated $40-100 \mathrm{~m}$, and (iv) old box replaced by a new box within 40-100 $\mathrm{m}$ from the original tree. Because frequency of use was not lower in boxes in original than in new trees, Korpimäki (1993) refuted the hypothesis. In a similar experimental setup in Sweden, Hipkiss et al. (2013) found no difference in frequency of box use between the original and the new trees. However, the design of the studies of Korpimäki (1993) and Hipkiss et al. (2013) makes their result difficult to evaluate. First, boxes were included in the experiment independent of previous use and nesting success, and this heterogeneity was not controlled for. Second, old nest material from any previous nesting had been removed for diet analysis (cf. Møller 1992), so the design eliminated any possibility the owls might have had to judge the cavity age from its content. Third, and most importantly, the owls were presented with only one box per locality. Therefore, choice of nest site could not be separated from choice of territory. Even if an owl judged a box to pose a significant predation risk, the owl may not have afforded to avoid the box because this would have meant loss of a breeding opportunity (cf. Mönkkönen et al. 2009), or a costly shift of territory (cf. Switzer 1993). In an area with high nest predation risk, Sonerud (1993) found an unchanged frequency of box use by Boreal Owl during the first 2 years after box relocation when no alternative box was present. When an owl has no alternative box to select in a territory, and when the content is the same in all boxes (old nest material from any previous nesting was present in the study by Sonerud (1993) and was removed in the study by Korpimäki (1993) and Hipkiss et al. (2013)), the focal owl would be less able to make an optimal selection.

Young Boreal Owl males appeared to use the information conveyed by the content of the box as the most important cue for selecting nest tree, i.e., new wood shavings being a proxy for a new cavity (see above). Therefore, the common practice among researchers to clean nest boxes used by Boreal Owls (cf. Korpimäki 1993; Hipkiss et al. 2013; Zarybnicka et al. 2015) may deceive these owls to select boxes that pose a significant predation risk in areas where the Pine Marten is common, thus creating an ecological trap (cf. Hale and Swearer 2016). This finding adds to the concern raised by Møller (1989, 1992, 1994), in general based on the fact that nest boxes deviate fundamentally from natural nest sites because they have been created by the researchers themselves, and in particular based on the fact that ornithologists routinely have removed old nest material from nest boxes without reporting it.

In conclusion, as more years elapsed since the successful nesting in the original nest tree, and the longer a box had been present there, the more likely Boreal Owls became to avoid the box in this tree and rather select the spatially new box for nesting. This would tend towards minimizing the risk of nest predation, because the probability of depredation of boreal nests in boxes has been found to increase with time since the box was installed and time since the previous successful nesting, probably resulting from long-term spatial memory in the predator (Sonerud 1985a, 1989, 1993).

Supplementary Information The online version contains supplementary material available at https://doi.org/10.1007/s10336-021-01876-y.

Acknowledgements This research adhered to the Association for the Study of Animal Behaviour Guidelines for the Use of Animals in Research, the legal requirements of Norway, and all institutional guidelines. I am especially grateful to $\mathrm{H}$. Steen for the help and companionship when installing and checking many of the nest boxes in 1990-94. I also would like to thank K. Eldegard, K. Fauchald, R. A. Ims, E. Maartmann and D. I. Sonerud for assistance during various parts of the field work, R. Steen for making the graphics, and S. Dale, V. Selås, T. Slagsvold, R. Steen and two anonymous referees for comments on drafts of the manuscript. This work was supported by grants from the Nansen Endowment (Grant numbers 102/87, 101/88, 111/89, 82/90, 97/91, 101/92, 203/93, 197b/94 and 87/95).

Author contribution GAS conceived, designed and executed this study and wrote the manuscript. No other person is entitled to authorship. 
Funding Open access funding provided by Norwegian University of Life Sciences.

Open Access This article is licensed under a Creative Commons Attribution 4.0 International License, which permits use, sharing, adaptation, distribution and reproduction in any medium or format, as long as you give appropriate credit to the original author(s) and the source, provide a link to the Creative Commons licence, and indicate if changes were made. The images or other third party material in this article are included in the article's Creative Commons licence, unless indicated otherwise in a credit line to the material. If material is not included in the article's Creative Commons licence and your intended use is not permitted by statutory regulation or exceeds the permitted use, you will need to obtain permission directly from the copyright holder. To view a copy of this licence, visit http://creativecommons.org/licenses/by/4.0/.

\section{References}

Aitken KEH, Wiebe KL, Martin K (2002) Nest-site reuse patterns for a cavity-nesting bird community in interior British Columbia. Auk 119:391-402. https://doi.org/10.1093/auk/119.2.391

Amo L, Visser ME, van Oers K (2011) Smelling out predators is innate in birds. Ardea 99:177-184. https://doi.org/10.5253/078.099.0207

Bellamy PE, Burgess MD, Mallord JW, Christinacce A, Orsman CJ, Davis T, Grice PV, Charman EC (2018) Nest predation and the influence of habitat structure on nest predation of wood warbler Phylloscopus sibilatrix, a ground-nesting forest passerine. J Ornithol 159:493-506. https://doi.org/10.1007/s10336-017-1527-7

Benson TJ, Brown JD, Bednarz JC (2010) Identifying predators clarifies predictors of nest success in a temperate passerine. J Anim Ecol 79:225-234. https://doi.org/10.1111/j.1365-2656.2009. 01604.x

Brainerd SM (1997) Habitat selection and range use by the Eurasian pine marten (Martes martes) in relation to commercial forestry practises in southern boreal Scandinavia. PhD dissertation, Agricultural University of Norway, ̊̊s

Brainerd SM, Helldin JO, Lindström ER, Rolstad E, Rolstad J, Storch I (1995) Pine marten (Martes martes) selection of resting and denning sites in Scandinavian managed forests. Ann Zool Fenn 32:151-157

Breisjøberget JI, Odden M, Wegge P, Zimmermann B, Andreassen H (2018) The alternative prey hypothesis revisited: still valid for willow ptarmigan population dynamics. PLoS ONE 13(6):e0197289. https://doi.org/10.1371/journal.pone.0197289

Caro T (2005) Antipredator defences in birds and mammals. University of Chicago Press, Chicago

Chalfoun AD, Martin TE (2010) Facultative nest patch shifts in response to predation risk in the Brewer's sparrow: a "win-stay, lose shift" strategy? Oecologia 163:885-892. https://doi.org/10. 1007/s00442-010-1679-0

Chalfoun AD, Schmidt KA (2012) Adaptive breeding-habitat selection: is it for the birds? Auk 12:589-599. https://doi.org/10.1525/ auk2012.129.4589

Clark RG, Shutler D (1999) Avian habitat selection: pattern from process in nest-site use by ducks? Ecology 80:272-287. https://doi. org/10.1890/0012-9658(1999)080[0272:AHSPFP]2.0.CO;2

Cramp S (1985) The birds of the western Palearctic, vol IV. Oxford University Press, Oxford

Dall SRX, Giraldeau L-A, Olsson O, McNamara JM, Stephens DW (2005) Information and its use by animals in evolutionary ecology. Trends Ecol Evol 20:187-193. https://doi.org/10.1016/j.tree. 2005.01.010
DeGregorio BA, Chiavacci SJ, Weatherhead PJ, Willson JD, Benson TJ, Sperry JH (2014) Snake predation on North American bird nest: culprits, patterns and future directions. J Avian Biol 45:325333. https://doi.org/10.1111/jav.00364

Diaz-Lora S, Martin-Vivaldi M, Garcia-Pelayo NJ, Garcia MA, Rodriguez-Ruano SM, Martinez-Bueno M, Soler JJ (2019) Experimental old nest material predicts hoopoe Upupa epops eggshell and uropygial gland microtbiota. J Avian Biol 2019:e02083. https:// doi.org/10.1111/jav.02083

Dow H, Fredga S (1983) Breeding and natal dispersal of the goldeneye, Bucephala clangula. J Anim Ecol 52:681-695. https://doi.org/ $10.2307 / 4447$

Dow H, Fredga S (1985) Selection of nest sites by a hole-nesting duck, the goldeneye Bucephala clangula. Ibis 127:16-30. https://doi. org/10.1111/j.1474-919X.1985.tb05034.x

Edworthy AB, Trzcinski MK, Cockle KL, Wiebe KL, Martin K (2018) Tree cavity occupancy by nesting vertebrates across cavity age. J Wild Manage 82:639-648. https://doi.org/10.1002/ jwmg. 21398

Eldegard K, Sonerud GA (2009) Female offspring desertion and maleonly care increase with natural and experimental increase in food abundance. Proc R Soc B 276:1713-1721. https://doi.org/10. 1098/rspb.2008.1775

Eldegard K, Sonerud GA (2010) Experimental increase in food supply influences the outcome of within-family conflicts in Tengmalm's owl. Behav Ecol Sociobiol 64:815-826. https://doi.org/10.1007/ s00265-009-0898-z

Eldegard K, Sonerud GA (2012) Sex roles during post-fledging care in birds: female Tengmalm's owls contribute little to food provisioning. J Ornithol 153:385-398. https://doi.org/10.1007/ s10336-011-0753-7

Elmberg J, Pöysä H (2011) Is the risk of nest predation heterospecifically density-dependent in precocial species belonging to different nesting guilds? Can J Zool 89:1164-1171. https://doi.org/10. 1139/Z11-093

Fontaine JJ, Martin TE (2006) Parent birds assess nest predation risk and adjust their reproductive strategies. Ecol Lett 9:428-434. https://doi.org/10.1111/j.1461-0248.2006.00892x

Haas CA (1998) Effects of prior nesting success on site fidelity and breeding dispersal: an experimental approach. Auk 115:929-936. https://doi.org/10.2307/4089511

Hakkarainen H, Korpimäki E (1998) Why do territorial male Tengmalm's owl fail to obtain a mate? Oecologia 114:578-582. https:// doi.org/10.1007/s004420050483

Hakkarainen H, Ilmonen P, Koivunen V, Korpimäki E (2001) Experimental increase of predation risk induces breeding dispersal of Tengmalm's owl. Oecologia 126:355-359. https://doi.org/10. $1007 / \mathrm{s} 004420000525$

Hale R, Swearer SE (2016) Ecological traps: current evidence and future direction. Proc R Soc B 283:20152647. https://doi.org/10. 1098/rspb.2015.2647

Helldin JO (1999) Diet, body condition, and reproduction of Eurasian pine martens Martes martes during cycles in microtine density. Ecography 22:324-336. https://doi.org/10.1111/j.1600-0587. 1999.tb00508.x

Helldin JO (2000) Seasonal diet of pine marten Martes martes in southern boreal Sweden. Acta Theriol 45:409-420

Hipkiss T, Gustafsson J, Eklund U, Hörnfeldt B (2013) Is the longterm decline of boreal owls in Sweden caused by avoidance of old boxes? J Raptor Res 47:15-20. https://doi.org/10.3356/ JRR-11-91.1

Hoover JP (2003) Decision rules for site fidelity in a migratory bird, the prothonotary warbler. Ecology 84:416-430. https://doi.org/10. 1890/0012-9658(2003)084[0416:DRFSFI]2.0.CO;2 
Hörnfeldt B, Carlsson B-G, Nordström Å (1988) Molt of primaries and age determination in Tengmalm's owl (Aegolius funereus). Auk 105:783-789

Hörnfeldt B, Carlsson B-G, Löfgren O, Eklund U (1990) Effects of cyclic food supply on breeding performance in Tengmalm's owl (Aegolius funereus). Can J Zool 68:522-530

Ibanez-Alamo JD, Magrath RD, Oteyza JC, Chalfoun AD, Haff TM, Schmidt KA, Thomson RL, Martin TE (2015) Nest predation research: recent findings and future perspectives. J Ornithol 156(Suppl 1):S247-S262. https://doi.org/10.1007/ s10336-015-1207-4

Jahren T, Storaas T, Willebrand T, Moa PF, Hagen B-R (2017) Impacts of voles and predators on nest predation in European boreal forest grouse. In: Jaren T (ed) (2017) The role of nest predation and nest predators in population declines of capercaillie and black grouse. PhD dissertation, Inland Norway University of Applied Sciences, Evenstad

Johnsson K (1993) The black woodpecker Dryocopus martius as a keystone species in forest. PhD dissertation, Swedish University of Agricultural Sciences, Uppsala

Johnsson K, Nilsson SG, Tjernberg M (1993) Characteristics and utilization of old black woodpecker holes by hole-nesting species. Ibis 135:410-416. https://doi.org/10.1111/j.1474-919X.1993. tb02113.x

Karell P, Ericsson P, Ericsson D, Haglund K, Morosinotto C, Nilsson L-O (2020) Mammalian nest predation induces small-scale nest site switching in territorial tawny owl (Strix aluco) females. Ornis Fenn 97:45-52

Koopman ME, McDonald DB, Hayward GD, Eldegard K, Sonerud GA, Sermach SG (2005) Genetic similarity among Eurasian subspecies of boreal owls Aegolius funereus. J Avian Biol 36:179-183. https://doi.org/10.1111/j.0908-8857.2005.03509.x

Korpimäki E (1993) Does nest-hole quality, poor breeding success or food depletion drive the breeding dispersal of Tengmalm's owls? J Anim Ecol 62:606-613. https://doi.org/10.2307/5382

Korpimäki E, Hakkarainen H (1991) Fluctuating food supply affects the clutch size of Tengmalm s owl independent of laying date. Oecologia 85:543-552. https://doi.org/10.1007/BF00323767

Korpimäki E, Lagerström M, Saurola P (1987) Field evidence for nomadism in Tengmalm's owl Aegolius funereus. Ornis Scand $18: 1-4$

Laaksonen T, Korpimäki E, Hakkarainen H (2002) Interactive effects of parental age and environmental variation on the breeding performance of Tengmalm's owls. J Anim Ecol 71:23-31. https://doi. org/10.1046/j.0021-8790.2001.00570.x

Latif QS, Heath SK, Rotenberry JT (2012) How avian nest site selection responds to predation risk: testing an "adaptive peak hypothesis.” J Anim Ecol 81:127-138. https://doi.org/10.1111/j.13652656.2011.01895.x

Leger DW, Didrichsons IA (1994) An assessment of data pooling and some alternatives. Anim Behav 48:823-832. https://doi.org/10. 1006/anbe.1994.1306

Li P, Martin TE (1991) Nest-site selection and nesting success of cavity-nesting birds in high elevation forest drainages. Auk 108:405418. https://doi.org/10.1093//auk/108.2.405

Lima SL (2009) Predators and the breeding bird: behavioral and reproductive flexibility under the risk of predation. Biol Rev 85:485513. https://doi.org/10.1111/j.1469-185X.2009.00085.x

Lindström ER, Brainerd SM, Helldin JO, Overskaug K (1995) Pine marten—red fox interactions: a case of intraguild predation? Ann Zool Fenn 32:123-130

Löfgren O, Hörnfeldt B, Carlsson B-G (1986) Site tenacity and nomadism in Tengmalm's owl (Aegolius funereus (L.)) in relation to cyclic food production. Oecologia 69:321-326. https://doi.org/ 10.1007/BF00377051
Luttbeg B (1996) A comparative bayes tactic for mate assessment and choice. Behav Ecol 7:451-460. https://doi.org/10.1093/beheco/ 7.4.451

Marchesi P (1989) Ecology of the pine marten (Martes martes L.) in the Swiss Jura mountains. PhD dissertation, University of Neuchatel, Neuchatel

Martin TE (1988) On the advantage of being different: nest predation and the coexistence of bird species. Proc Natl Acad Sci USA 85:2196-2199. https://doi.org/10.1073/pnas.85.7.2196

Martin TE (1995) Avian life history evolution in relation to nest sites, nest predation, and food. Ecol Monogr 65:101-127. https://doi. org/10.2307/2937160

Martin TE (1998) Are microhabitat preferences of coexisting species under selection and adaptive? Ecology 79:656-670. https://doi. org/10.1890/0012-9658(1998)079[0656:AMPOCS]2.0.CO;2

Martin TE, Clobert J (1996) Nest predation and avian life-history evolution in Europe versus North America: a possible role of humans? Am Nat 147:1028-1046. https://doi.org/10.1086/285891

Martin TE, Li P (1992) Life history traits of open- vs. cavity-nesting birds. Ecology 73:579-592. https://doi.org/10.2307/1940764

Martin TE, Scott J, Menge C (2000) Nest predation increases with parental activity: separating nest site and parental activity effects. Proc R Soc B 267:2287-2293. https://doi.org/10.1098/ rsbp.2001.1879

Mazgajski TD (2007) Effect of old nest material on nest site selection and breeding parameters in secondary hole nesters-a review. Acta Ornithol 42:1-14. https://doi.org/10.3161/068.042.0107

Mitchell WA, Lima SL (2002) Predator-prey shell games: large-scale movements and its implications for decision-making by prey. Oikos 99:249-259. https://doi.org/10.1034/j.1600-0706.2002. 990205.x

Møller AP (1989) Parasites, predators and nest boxes: facts and artefacts in nest box studies of birds? Oikos 56:421-423. https:// doi.org/10.2307/3565628

Møller AP (1992) Nest boxes and the scientific rigour of experimental studies. Oikos 63:309-311. https://doi.org/10.2307/3545393

Møller AP (1994) Facts and artefacts in nest-box studies: implications for studies of birds of prey. J Raptor Res 28:143-148

Mönkkönen M, Forsman J, Kananoja T, Ylönen H (2009) Indirect cues of nest predation risk and avian reproductive decisions. Biol Lett 5:176-178. https://doi.org/10.1098/rsbl.2008.0631

Mysterud I (1970) Hypotheses concerning characteristics and causes of population movements in Tengmalm's owls (Aegolius funereus (L)). Nytt Mag Zool 18:49-74

Nilsson SG, Johnson K, Tjernberg M (1991) Is avoidance by black woodpeckers of old nest holes due to predators? Anim Behav 41:439-441. https://doi.org/10.1016/S0003-3472(05)-80845-0

Otterbeck A, Selås V, Nielsen JT, Roualet E, Lindén A (2019) The paradox of nest reuse: early breeding benefits reproduction, but nest reuse increase nest predation risk. Oecologia 190:559-568. https://doi.org/10.1007/s00442-019-04436-7

Podofillini S, Cecere JG, Griggio M, Curcio A, De Capua EL, Fulco E, Pirrello S, Saino N, Serra L, Visceglia M, Rubolini D (2018) Home, dirty home: effect of old nest material on nest-site selection and breeding performance in a cavity-nesting raptor. Curr Zool 64:693-702. https://doi.org/10.1093/cz//zoy012

Pöysä H (1999) Conspecific nest parasitism is associated with inequality in nest predation in the common goldeneye (Bucephala clangula). Behav Ecol 10:533-540. https://doi.org/10.1093/ beheco/10.5.533

Pöysä H, Jalava K, Paasivaara A (2016) Generalist predator, cyclic voles and cavity nests: testing the alternative prey hypothesis. Oecologia 182:1083-1093. https://doi.org/10.1007/ s00442-016-3728-9 
Pulliainen E, Ollimäki P (1996) A long-term study of the winter food niche of the pine marten Martes martes in northern boreal Finland. Acta Theriol 41:337-352

Riding CS, Belthoff JR (2015) Removal of old nest material decreases reuse of artificial burrows by burrowing owls. Wildl Soc Bull 39:521-528. https://doi.org/10.1002/wsb.552

Rolstad J, Rolstad E, Sæteren Ø (2000) Black woodpecker nest sites: characteristics, selection, and reproductive success. J Wildl Manage 64:1053-1066. https://doi.org/10.2307/3803216

SAS (2012) JMP® Pro version 10. SAS Institute, Cary

Schmidt KA, Whelan CJ (1999) Nest placement and mortality: is nest predation a random event in space and time? Condor 101:916-920. https://doi.org/10.2307/1370089

Schmidt KA, Ostfeld RS, Smyth KN (2006) Spatial heterogeneity in predator activity, nest survivorship, and nest-site selection in two forest thrushes. Oecologia 148:22-29. https://doi.org/ 10.1007/s00442-005-0340-9

Schmidt KA, Dall SRX, van Gils JA (2010) The ecology of information: an overview on the ecological significance of making informed decisions. Oikos 119:304-316. https://doi.org/10.1111/j. 1600-0706.2009.17573.x

Selås V (1998) Does food competition from red fox (Vulpes vulpes) influence the breeding density of goshawk (Accipiter gentilis)? Evidence from a natural experiment. J Zool Lond 246:325-335. https://doi.org/10.1111/j.1469-7998.1998.tb00162.x

Shitikov D, Vaytina T, Makarova T, Fedotova S, Volkova V, Samsonov S (2018) Species-specific nest predation depends on the total passerine nest density in open-nesting passerines. J Ornithol 159:483-491. https://doi.org/10.1007/s10336-017-1526-8

Smedshaug CA, Selås V, Lund SE, Sonerud GA (1999) The effect of a natural reduction of red fox Vulpes vulpes on small game hunting bags in Norway. Wildl Biol 5:157-166. https://doi.org/10.2981/ wlb. 1999.020

Sonerud GA (1985a) Nest hole shift in Tengmalm's owl Aegolius funereus as defence against nest predation involving long-term memory in the predator. J Anim Ecol 54:179-192. https://doi. org/10.2307/4629

Sonerud GA (1985b) Risk of nest predation in three species of hole nesting owls: influence on choice of nesting habitat and incubation behaviour. Ornis Scand 16:261-269. https://doi.org/10.2307/ 3676689
Sonerud GA (1989) Reduced predation by pine martens on nests of Tengmalm's owl in relocated boxes. Anim Behav 37:332-334. https://doi.org/10.1016/0003-3472(89)90122-X

Sonerud GA (1993) Reduced predation by nest box relocation: differential effect on natural and artificial Tengmalm's owl nests. Ornis Scand 24:249-253. https://doi.org/10.2307/3676742

Sonerud GA, Solheim R, Prestrud K (1988) Dispersal of Tengmalm's owl Aegolius funereus in relation to prey availability and nesting success. Ornis Scand 19:175-181. https://doi.org/10.2307/36765 55

Statistics Norway. 2020. Småvilt- og rådyrjakt. ssb.no accessed 11 July 2020.

Steen H, Ims RA, Sonerud GA (1996) Spatial and temporal patterns of small-rodent population dynamics at a regional scale. Ecology 77:2365-2372. https://doi.org/10.2307/2265738

Storch I, Lindström E, de Jounge J (1990) Diet and habitat selection of the pine marten in relation to competition with the red fox. Acta Theriol 35:311-320

Sumasgutner P, Vasko V, Varjonen R, Korpimäki E (2014) Public information revealed by pellets in nest sites is more important than ecto-parasite avoidance in the settlement decisions of Eurasian kestrels. Behav Ecol Sociobiol 68:2023-2034. https://doi.org/10. 1007/s00265-014-1808-6

Switzer PV (1993) Site fidelity in predictable and unpredictable habitats. Evol Ecol 7:533-555. https://doi.org/10.1007/BF01237820

Wesolowski T (2011) "Lifespan" of woodpecker-made holes in a primeval temperate forest: a thirty year study. Forest Ecol Manage 262:1846-1852. https://doi.org/10.1016/j.foreco.2011.08.001

Wiebe K, Koenig WD, Martin K (2007) Costs and benefits of nest reuse versus excavation in cavity-nesting birds. Ann Zool Fennici 44:209-217

Zarybnicka M, Riegert J, Kouba M (2015) Indirect food web interactions affect predation of Tengmalm's owls Aegolius funereus nests by pine martens Martes martes according to the alternative prey hypothesis. Ibis 157:459-467. https://doi.org/10.1111/ibi.12265

Publisher's Note Springer Nature remains neutral with regard to jurisdictional claims in published maps and institutional affiliations. 